\title{
Strength and F O S Performance of Black Cotton Soil Treated with Calcium Chloride
}

\author{
Dr. K.V. Manoj Krishna and Dr. H.N.Ramesh ${ }^{2}$ \\ ${ }^{1}$ Department of Civil Engineering, Govt. S K S J T I, K.R.Circle, Bangalore-560001, India \\ ${ }^{2}$ Department of Civil Engineering, UVCE, J.B.Campus, Bangalore University, Bangalore-560056, India
}

\begin{abstract}
Black cotton soil is a typical expansive soil which loses its strength in presence of water résultant in swelling of the soil and in absence of water it shows multiple cracks due to shrinkage. Present paper describes the strength behaviour of Black cotton soil treated with calcium chloride $\left(\mathrm{CaCl}_{2}\right)$. From the immediate compaction and unconfined compressive strength test up to 30 days of curing, it was observed that Black Cotton Soil with $3 \% \mathrm{CaCl}_{2}$ (by weight of soil) combination found to be optimum percentage. Direct shear test was conducted under soaked condition with various curing periods, Safe Bearing Capacity determined as per IS codal practice. In this paper an approach is also made to give a comparison of improvement in factor of safety of the black cotton soil treated with calcium chloride with black cotton soil alone. It is found that addition of 3\% calcium chloride has shown higher factor of safety with higher curing periods for an embankment slope of 1:2.5.

Keywords -Maximum dry density, unconfined compressive strength, Factor of Safety
\end{abstract}

\section{INTRODUCTION}

The Black Cotton Soils cover about $20 \%$ of land area in India and are predominantly located in the Deccan trap covering the states of Maharashtra, Gujarat, Madhya Pradesh, Karnataka, Andhra Pradesh, Tamil Nadu, Uttar Pradesh and Rajasthan. It is also called as regur or black soil. . Most Indian Black Cotton soils are rich in Montmorillonate, a type of clay mineral. This mineral is responsible for swell-shrink behaviour of the soil. Hence it is interesting to study the disparity in the behaviour of Black Cotton soil containing Montmorillonitic with respect to Black Cotton soil containing interstratified mineral. The soil varies in colour from grey to deep black. In the beginning it was considered that black colour was due to the presence of humidified organic matter. Subsequent work has however, shown that the colour is due to small concentration of titanium oxide. The natural soil has been collected from Tumkur District, India. Tumkur is situated in Southern Karnataka Plateau, a part of Deccan Plateau of India. The Geographical coordinates of Kadaba area: Latitude: $12^{\circ} 44^{\prime} 0 "$ "North and Longitude: $75^{\circ} 28^{\prime} 00^{\prime \prime}$ East. Altitude of the place is 93.878 meters.

The nearest Highway located from where the soil was collected is NH 206. The soil was excavated from a depth of 2 meters below the Natural Ground Level. The depth of water table is around 350-700 meters below the Natural Ground Level. Water logging in rainy season is hardly noticed and the ground is seen dry through out the year. The crops grown are rice, ragi, etc. Cracks can be noticed in the buildings near the site from where the soil was collected. So this problematic soil has stabilized by adding appropriate material and using suitable ground improvement technique. Addition of $3 \%$ of $\mathrm{CaCl}_{2}$ increases Unconfined Compressive strength. Its addition decreases the rate of evaporation by lowering the vapor pressure of Water and by increasing the Surface Tension. It also facilitates compaction so that the desired density is obtained with comparatively less compactive effort Phani et al, (1998) [1] . Plasticity index of clay bed is decreased by 40\%$60 \%$ with $\mathrm{CaCl}_{2}$ treatment on black cotton .soil. It is revealed that the modification of clay properties with $\mathrm{CaCl}_{2}$ is several times greater than conventionally used lime. and the field cyclic seasonal movements and laboratory tests on Undisturbed and Disturbed Black Cotton Soil samples revealed that the $\mathrm{CaCl}_{2}$ could be a promising chemical modifier instead of conventionally used lime not only due to its multifold influence on heave control, plasticity reduction and swell properties but also its easy application in the form of solution with out any need for pulverization and mixing Ramana Murthy and Hari Krishna (2007) [2]. Black cotton soil with lime have low solubility of lime and mixing problem involved. It is reported that $\mathrm{CaCl}_{2}$ could be an effective alternative to conventional lime treatment. From literature it is concluded that $\mathrm{CaCl}_{2}$ can also be used for Ground improvement Manchikanti (2008) [3]. From the above literature survey, it is observed that Calcium Chloride is a best alternative to Lime or Cement. So an attempt is done to study the strength behaviour of black cotton soil treated with calcium chloride. 


\section{MATERIALS AND METHODS}

\subsection{Materials}

\subsubsection{Black cotton soil}

For the present research work soil was collected from Kadaba Hobali, Gubbi Taluk, Tumkur District at a depth of $2 \mathrm{~m}$ from the Natural Ground Level. The obtained soil was air dried and pulverized manually and for this research work soil passing through $425 \mu$ IS sieve was used, except for sieve analysis. The physical properties of the collected red earth soil are presented in Table 1.Plate.1 shows place at which soil was collected.
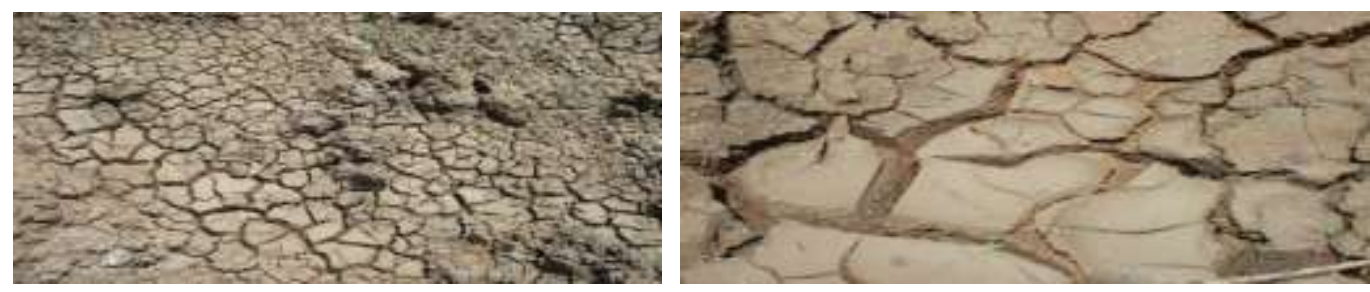

Plate.1 Place at which soil was collected.

\subsubsection{Lime}

Calcium Chloride [Fused] $\mathrm{CaCl}_{2}=110.99 \mathrm{MW}$ is obtained from Nice Chemicals Pvt Ltd. P.B.No.2217, Manimala Road, Edappally Kochi-682024, Kerala, India is used in this present investigation. The chemical properties of Calcium Chloride are shown in Table 2.

\subsection{Methodology adopted:}

The compaction tests were conducted using mini compaction test apparatus Sridharan and Shivapullaiah [2005] [4], and few results were compared with light compaction test as per IS: 2720.(Part-7) .(1980) [5],it is found to be almost same. Hence, for all compaction tests were conducted using mini compaction test apparatus. Unconfined compressive strength tests were carried out as per IS: 2720 (part 10)-1973[6], for various combinations of mine tailings treated red earth with lime. All samples were prepared at respective maximum dry density and optimum moisture content for an aspect ratio of 2.0. Consistency of the strength results were maintained by validating minimum three samples in one combination. Direct shear test were conducted as per IS 2720(part 13) - 1986[7].The prepared samples were kept in desiccators to maintained 100\% humidity for prolong curing periods.

\section{RESULTS AND DISCUSSIONS}

\subsection{Dry density -water content of Black cotton soil treated with calcium chloride}

It has been observed in general, that addition of calcium chloride to black cotton soil with different percentages reduces maximum dry density and increases optimum moisture content up to optimum percentage at optimum percentage maximum dry density increases and optimum moisture content increases and there after trend reverses. The density increases at optimum percentage of calcium chloride in black cotton soil there after density reduces, this is due to critical change of the soil structure from flocculated state to dispersed state. Same trend were observed in accordance with Gullapalli Sankara(2006) [8]. From above discussion it was observed that $3 \%$ of $\mathrm{CaCl}_{2}$ is the optimum percentage at which the density increases and moisture content decreases as shown in Fig. 1

\subsection{Unconfined compressive strength}

The unconfined compressive strength test is conducted at a strain rate of $1.25 \mathrm{~mm} / \mathrm{min}$ as per IS: 2720 standards. The unconfined compressive strength samples were prepared by mixing soil with $1 \%$ to $6 \%$ of $\mathrm{CaCl}_{2}$ (by weight of soil) at their corresponding maximum dry density and optimum moisture content. The samples were tested immediately as well as with various curing periods.

From the above unconfined compressive strength test it is observed that on addition of various percentages of $\mathrm{CaCl}_{2}$ with prolong curing periods, strength increases for all combinations, however the magnitude of increase in the unconfined compressive strength is 17 folds at $3 \% \mathrm{CaCl}_{2}$ combination in Black Cotton soil compare to black cotton soil alone at 30 days curing. This is because up to $3 \% \mathrm{CaCl}_{2}$ added to the soil in presence of water forms cluster, this cluster will hold the soil particles together thereby increases the strength immediately. As curing days increases the bonding strength of the soil will also increases up to critical days. Beyond which breakage of cluster leads to decrease in strength. Ramesh et al (2005) [9]. As shown in Table 3 and Fig. 2 


\subsection{Shear strength Black cotton soil treated with Calcium Chloride}

The Shear Strength of the soil is the resistance to deformation by continuous shear displacement of soil upon the action of shear stress. The Shear Strength of soil can be separated into two components known as Shear Strength parameters; the Cohesion and the angle of internal friction.

As the various percentage of calcium chloride is added to black cotton soil, the angle of internal friction and cohesion increases, this is because as the calcium chloride is added to soil cluster formation take place as the curing period increases densification of cluster increases hence frictional value also increases. From Table. 4. It indicates that addition of calcium chloride increases the safe bearing capacity of the black cotton soil by 12 to 15 folds on compared with soil alone.

\subsubsection{Design of embankment using soil treated with calcium chloride}

Addition of Calcareous material will increase the bonding strength between the particles and hence increase in the Cohesion (C )and angle of internal friction $(\Phi)$ values. Thus the increase in $\mathrm{c}$ and $\Phi$ values will increase the stable slope in terms of increase in factor of safety. Table 5 and Fig. 3 it is observed that the factor of safety increases with addition of various percentages of Calcium Chloride to black cotton soil by 56\% 69\% and $88 \%$ for embankment slopes 1: 1.5,1:2 and 1:2.5 respectively. On compared with black cotton soil with various percentage of calcium chloride, $3 \%$ calcium chloride treated black cotton soil shown higher increase in factory of safety. However, for an embankment slope of 1: 2.5 shows higher percentage of factory of safety on compared with other slopes.

\section{CONCLUSION}

Based on the results presented in this paper, the following conclusions are drawn

(I). Black cotton soil with 3\% calcium chloride shows higher maximum dry density and minimum optimum moisture content

(II). Black cotton soil with $3 \%$ calcium chloride shows 17 folds increase in strength on compared with soil alone at 30 days curing.

(III) Black cotton soil treated with 3\% calcium chloride shows higher shear strength parameters and safe bearing capacity of the soil is increases by 12 to 15 folds on compared with soil alone.

(iv) Black cotton soil treated with 3\% calcium chloride shows 1:2.5 as optimum embankment slope which gives highest factor of safety on compared with soil alone.

\section{References}

[1] B.R. Phani kumar, V.Ramesh, M.V.B Ramana Sastry..(1998), Efficiency of Calcium Chloride in stabilizing swelling soils, Indian Geotechnical Conference. New Delhi.

[2] V.Ramana Murthy and P.Hari Krishna (2007),Amelioration of expansive clay slopes using Calcium Chloride, J.Mat in Civil Engg 19, 1.

[3] S.Manchikanti. (2008),A laboratory study on the effect of electrolytes on properties of expansive soil used in pavement sub grade, 88 .

[4] A. Sridharan, and P.V.Sivapullaiah, (2005,Mini compaction test apparatus for fine grained soils, Geotechnical Testing Journal, ASTM Intl, 28(3), 1-20.

[5]. IS: 2720.(Part-7) .(1980),Methods of Test for soils, Determination of Water content-Dry Density Relation using Light Compaction, (second revision),(Amendment 2), Reaffirmed 1987.

[6]. IS 2720(part 10) - (1973), Methods of tests for soils: part 10 determination of uniform compressive strength.

[7]. IS 2720(part 13) - (1986), Methods of tests for soils: part 13 determination of shear parameters.

[8]. Gullapalli Sankara, (2006),Geotechnical behaviour of soil containing mixed layered illite - smectite contaminated with caustic alkali, Ph.D thesis submitted to IISc.

[9]. H.N. Ramesh., H.S. Nanda,. And K.V. Manoj Krishna (2005),Effect of lime and sodium salts on the geotechnical properties of Shedi soil, Proceedings of Indian Geotechnical Conference, $, 2,177-180$

\section{Acknowledgement}

We sincerely thank my ex-employer Dayananda Sagar College of Engineering, my friend Dr. B.V.Kiran Kumar and former our project students Ayaz Ali Khan, Chandramouli.Y.J, Md Azmath Ali, Zakaulla Shariff for their support during the laboratory experiments for the above work. 


\section{FIGURES AND TABLES}

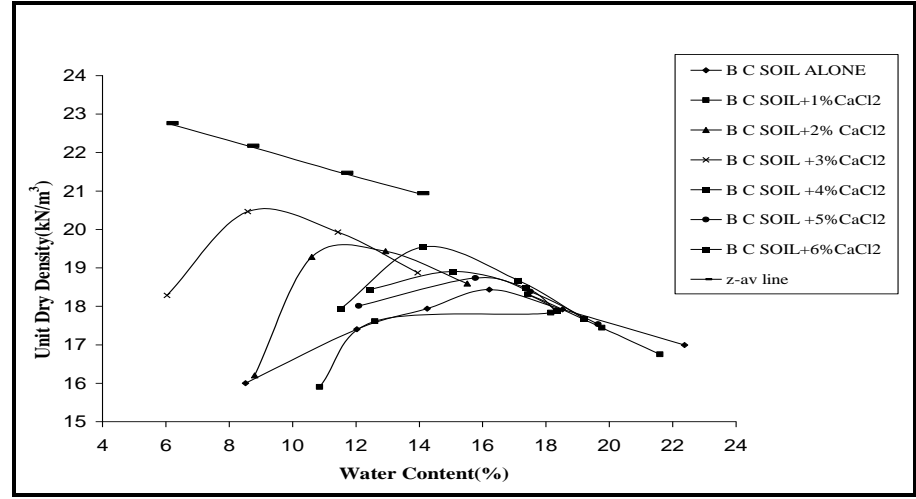

Fig.1 Density-water content relationship of Black cotton soil Treated with Various Percentage of Calcium Chloride

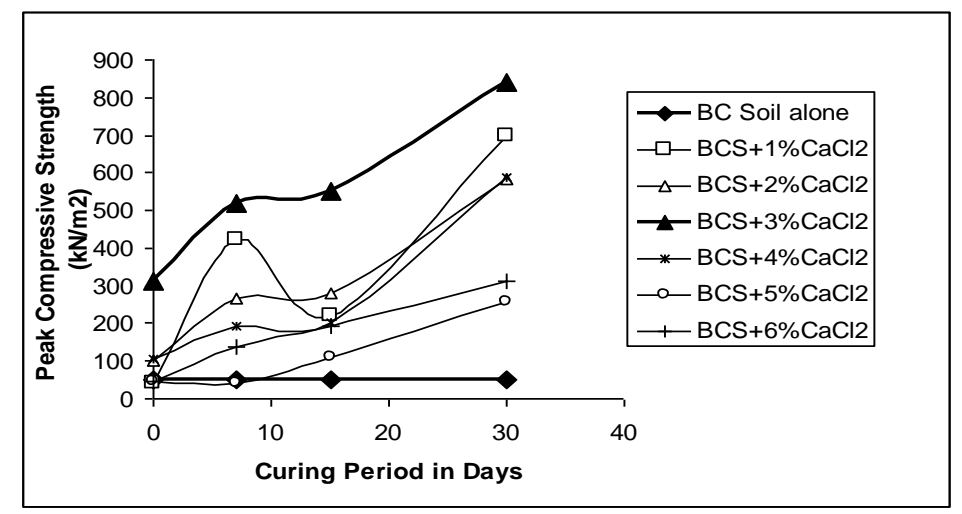

Fig.2 Unconfined Compressive Strength of Black cotton soil treated with Various Percentage of Calcium Chloride with curing

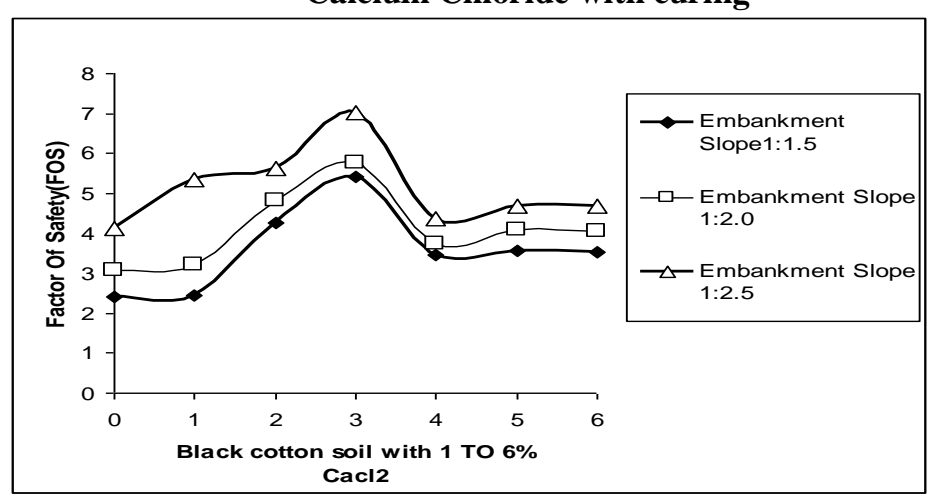

Fig.3 Variation of Factor of Safety(FOS) of Black Cotton Soil Treated with Various Percentage of Calcium Chloride

Table.1 Basic properties of Black Cotton Soil

\begin{tabular}{|lc|c|}
\hline \multicolumn{1}{|c|}{ Test } & Values \\
\hline Natural Moisture Content & $(\%)$ & 5.538 \\
\hline Liquid limit & $(\%)$ & 65.500 \\
\hline Plastic limit & $(\%)$ & 22.710 \\
\hline Shrinkage limit & $(\%)$ & 21.840 \\
\hline Plasticity Index & $(\%)$ & 42.780 \\
\hline Sand & $(\%)$ & 30.000 \\
\hline Silt and Clay size fraction & $(\%)$ & 70.000 \\
\hline Grain Specific Gravity & 2.310 \\
\hline
\end{tabular}


Strength and F O S Performance of Black Cotton Soil Treated with Calcium Chloride

\begin{tabular}{|c|c|}
\hline \multicolumn{2}{|l|}{ "Compaction Characteristics } \\
\hline Optimum Moisture Content & 16.200 \\
\hline Maximum Dry Density & 18.080 \\
\hline Coefficient Of Permeability & $6.41 \times 10^{-5}$ \\
\hline \multicolumn{2}{|l|}{ Consolidation Characteristics: } \\
\hline Coefficient of Consolidation $(\mathrm{Cv})\left(\mathrm{cm}^{2} / \mathrm{sec}\right)$ & $1.68 \times 10^{-3}$ \\
\hline Compression Index (Cc) & 0.148 \\
\hline Pre consolidation Pressure & 61.000 \\
\hline \multicolumn{2}{|l|}{ Shear Strength Parameters: } \\
\hline Angle of Internal Friction ( $\Phi$ ) & $32^{0}$ \\
\hline Cohesion (c ) & 36.500 \\
\hline $\begin{array}{l}\text { Unconfined Compressive Strength at OMC- } \\
\text { MDD at a strain rate of }\left(\mathrm{kN} / \mathrm{m}^{2}\right)\end{array}$ & 49.749 \\
\hline
\end{tabular}

Table 2. Chemical Composition of Lime

\begin{tabular}{|c|c|}
\hline Item & Percentage \\
\hline Assay & $90 \%$ \\
\hline $\mathrm{CaCl}_{2}$ & 110.99 \\
\hline
\end{tabular}

Table. 3 Unconfined Compressive Strength of Black Cotton Soil Treated with Calcium Chloride with Various Curing periods

\begin{tabular}{|c|c|c|c|c|}
\hline \multirow{2}{*}{ Mixture } & \multicolumn{4}{|c|}{ Unconfined Compressive Strength $(\mathbf{C C S})\left(\mathbf{k N} / \mathbf{~ m}^{\mathbf{2}}\right)$} \\
\cline { 2 - 5 } & \multicolumn{4}{|c|}{$\mathbf{0}$} \\
\cline { 2 - 5 } & $\mathbf{0}$ & $\mathbf{7}$ & $\mathbf{1 5}$ & $\mathbf{3 0}$ \\
\hline $\mathrm{BC}$ soil alone & 49.490 & 49.490 & 49.490 & 49.490 \\
\hline $\mathrm{BC} \mathrm{Soil}+1 \% \mathrm{CaCl}_{2}$ & 43.830 & 424.770 & 229.020 & 699.450 \\
\hline $\mathrm{BC}$ soil $+2 \% \mathrm{CaCl}_{2}$ & 99.960 & 267.810 & 278.120 & 583.100 \\
\hline $\mathrm{BC}$ soil $+3 \% \mathrm{CaCl}_{2}$ & 311.270 & 518.940 & 553.610 & 840.240 \\
\hline $\mathrm{BC}$ soil $+4 \% \mathrm{CaCl}_{2}$ & 106.240 & 194.950 & 202.320 & 589.000 \\
\hline $\mathrm{BC}$ soil $+5 \% \mathrm{CaCl}_{2}$ & 44.920 & 41.870 & 112.800 & 256.830 \\
\hline $\mathrm{BC}$ soil $+6 \% \mathrm{CaCl}_{2}$ & 45.320 & 140.280 & 191.600 & 311.850 \\
\hline
\end{tabular}

Table.4 Safe Bearing Capacity of Black Cotton Soil Treated with Various Percentage of Calcium Chloride with Curing.

\begin{tabular}{|l|c|c|}
\hline \multirow{2}{*}{ Mixture } & \multicolumn{2}{|c|}{ Safe Bearing Capacity $\left(\mathrm{kN} / \mathrm{m}^{2}\right)$} \\
\cline { 2 - 3 } & \multicolumn{2}{|c|}{ Curing in days } \\
\cline { 2 - 3 } & Immediate & 7 Days \\
\hline B.C. soil Alone & 1306 & 1306 \\
\hline B.C. soil $+1 \% \mathrm{CaCl}_{2}$ & 5537 & 27807 \\
\hline B.C. soil $+2 \% \mathrm{CaCl}_{2}$ & 6307 & 4296 \\
\hline B.C. soil $+3 \% \mathrm{CaCl}_{2}$ & 20610 & 17021 \\
\hline B.C. soil $+4 \% \mathrm{CaCl}_{2}$ & 1543 & 4137 \\
\hline B.C. soil $+5 \% \mathrm{CaCl}_{2}$ & 2568 & 2934 \\
\hline B.C. soil $+6 \% \mathrm{CaCl}_{2}$ & 2636 & 5198 \\
\hline
\end{tabular}

Table.5 Variation of Factor of Safety of Black Cotton Soil Treated with Various Percentage of Calcium Chloride

\begin{tabular}{|l|c|c|c|}
\hline \multirow{2}{*}{ Mixture } & \multicolumn{3}{|c|}{ Factor of Safety } \\
\cline { 2 - 4 } & Slope $1: 1.5$ & Slope $1: 2$ & Slope $1: 2.5$ \\
\hline B.C Soil Alone & 2.40 & 3.06 & 4.13 \\
\hline B.C Soil $+1 \% \mathrm{CaCl}_{2}$ & 2.45 & 3.21 & 5.34 \\
\hline B.C Soil $+2 \% \mathrm{CaCl}_{2}$ & 4.25 & 4.83 & 5.61 \\
\hline B.C Soil $+3 \% \mathrm{CaCl}_{2}$ & 5.43 & 5.77 & 7.01 \\
\hline B.C Soil $+4 \% \mathrm{CaCl}_{2}$ & 3.45 & 3.74 & 4.36 \\
\hline B.C Soil $+5 \% \mathrm{CaCl}_{2}$ & 3.56 & 4.08 & 4.69 \\
\hline B.C Soil $+6 \% \mathrm{CaCl}_{2}$ & 3.53 & 4.05 & 4.69 \\
\hline
\end{tabular}

